\title{
The Influence of Identity on Students' Learning Experiences in an English as Foreign Language Programme in a Saudi Medical University
}

\author{
Sajjadllah Alhawsawi \\ English Department, College of Science and Health Professions King Saud bin Abdulaziz University for Health Sciences Riyadh, Kingdom \\ of Saudi Arabia
}

Email address:

hawsawis@ksau-hs.edu.sa

To cite this article:

Sajjadllah Alhawsawi. The Influence of Identity on Students' Learning Experiences in an English as Foreign Language Programme in a Saudi Medical University. Education Journal. Vol. 4, No. 4, 2015, pp. 149-157. doi: 10.11648/j.edu.20150404.12

\begin{abstract}
Our identities influence our actions and how we conduct ourselves. The construction of these identities is influenced by factors beyond our individuality and that in turn influences the way a person learn. Different studies in the field on English language learning emphasize the impact of identities in learning English as Foreign Language. However, in the context of Saudi higher education this notion remains unexplored. This paper presents findings form an English as Foreign Language (EFL) programme in a Saudi Medical University that illustrate the influence of different identities on students' learning experience in. It highlights how identities associated with students' socioeconomic back ground as well as disciplines of study influence students' learning experience.
\end{abstract}

Keywords: EFL, Identity, Learning experience

\section{Introduction}

Identity is one of many social issues that influence students' learning experiences in higher education. Being labelled as a student does not cancel the other identities that a person has as the social, cultural and political sphere; all play a role in the construction of a person identity (Peirce 1995, Weedon 1997, Bucholtz and Hall 2005, McKinney and Norton 2008). This means that the different roles or belongings that a person has contribute to the construction of one's identities. Student identity can be influenced by the different social associations that $\mathrm{s} / \mathrm{he}$ has. A student continues to be a son or a daughter; a brother or a sister; a male or a female; minority or majority, advantaged or disadvantaged and many other identities. All these aspects of a person life construct various identities, which influence the way a student experiences her/his learning in higher education and helps to shape individual practices and how a person responds to an educational settings (Trowler \& Cooper 2002, Barnawi 2009). The view of 'self' influences the way teachers and students interact in educational setting and how students experience their learning (Trowler \& Cooper 2002, Ashwin 2009). The literature on English language learning (e.g. Norton and Toohey 2000, Mayes 2010 and Talmy 2010) stresses the importance of understanding students' identity in the context of language learning, as this helps highlight the relationship between the learners and the real world and emphasise the influence of identities in the process of knowledge production and language learning.

Most studies about English as Foreign Language (EFL) in Saudi Arabia (SA) focus on aspects of the psychology of language learning. Issues such as motivation (e.g. Al-Shehri 2009), learning strategies (i.e. Vann and Abraham 1990; McMullen 2009) and people's attitude toward the English language (Al-Abed Al Haq and Smadi 1996) are widely discussed. Despite the proven usefulness of analysing learners' identities in EFL learning (Peirce 1995, Norton and Toohey 2000, Barnawi 2009), such an angle to investigating EFL learning has not received attention in the context of SA. Thus, this study attempt steer the discussion on such a topic.

\subsection{Conceptualizing Identity}

Contrary to the old individualistic perceptions of identity, where it was seen as a fixed and stable description of individuals by themselves, with every person seen as having a unique but fixed and coherent self (Bucholtz and Hall 2005), Weedon conceptualises identity as "the conscious and unconscious thoughts and emotions of the individual, her 
sense of herself and her ways of understanding her relation to the world" (1987:32). It is not only about what a person thinks or feels but also about the unconsciousness that individuals are not aware of but plays a role in influencing the self. This acknowledges the social nature of individuals, who construct their identity in relation to the social world. Therefore, identities can be understood as "the social positioning of self and other" (Bucholtz and Hall 2005: 586). It is the positionality of the self in relation to the others in the social world that reflects us who we are, and this positionality is influenced by and influences our social roles (Hall 1990). Since people are always in constant disposition as they establish relationship with the social world, their identities are "seen as a production which is never complete, always in process and always constituted within, not outside, representation" Hall 1990: 226). McKinney and Norton (2008:194) emphasise the aspect of historical embeddedness in their definition of identity as they argue that it is "discursively constructed, and as always socially and historically embedded. Identity is thus always in process, a site of struggle between competing discourses in which the subject plays an active role". Through these different social roles and the shared experiences, a person gains a sense of self and meaning. Therefore different aspects of identity could be seen as different positions that an individual might position themselves in and these positions are constantly changing and taking different shape depending on the investment and the capital at stake at the time of assuming the position (McKinney and Norton 2008). This means that a person may take a position of being a father at home but an influential manager at work and a rich friend in a coffee shop however, these positions are interlinked and inform each other in different ways.

Therefore, I can argue that being a 'student' is a position that identifies a student in higher education but this position is interlinked with other roles and associations that the students might have such as being socioeconomically advantaged/disadvantaged, male/female, belonging to certain racial group or studying a particular discipline. These positions are not separated from an individual's personal history, previous experiences and prevailing social values. Thus, in this paper identity is a combination of different labels/identities that influence students learning experiences.

\subsection{Learning Experience}

Learning experiences is fluid concept that can encompass different factors that can influence learning. Thus the definition of the learning experience is very much dependant on how learning is being defined. The individualistic view to learning perceives leaning as process of stimulus and response where issues of learning strategies and motivation are key in explaining how learning is being experienced (Biggs 1993; 2001; Entwistle and Ramsden 1982). A sociological view to learning identify learning as a social phenomenon that is influenced by different elements of social structures such as gender, race, social class and powerrelations (Solomon 2007; Trowler 2009; Becher and Trowler
2001; Lea and Stierer 2000; Becher and Parry 2005). This paper views learning as an individual choice that has its roots within the person's mind, gained and influenced by the teaching and learning approaches imposed on the learner. These choices are influenced by the social structures surrounding the learning and the learner. Thus, learning experience here means a way in which a student interacts with different structural and individualistic factors that can impact on the way person gains knowledge.

\subsection{Identity and Language Learning}

Research on identity and language learning investigates different issues. One these issues is the impact of identity on the learning experience of individuals when learning English language (Maclean 2010, Starfield 2002). For example professional identity that students adopt seems to influence the writing skills and the kind of text students are able to produce (Maclean 2010). In a study Maclean (2010) notes that some of difficulty that first-year law students exhibited in writing was not a result of their weak linguistic competencies but it was a result of the tension between their current identity i.e. being a student and the desired one i.e. to be a law practitioner. This tension between the academic and the professional "positioning" confuses the students and subsequently influences the way they express themselves in writing (Maclean 2010:192). Belong to a certain social background is also reported as an identity that could influence students' learning experience. Starfield (2002) investigates how the students' social background in South Africa influences their authoritative voice in their academic writing and subsequently influences their success or failure in their study. Drawing on Bourdieu concept of cultural capital and habitus, he argues that students who are socially advantaged are able to "construct a powerful, authoritative textual and discoursal identity" (Starfield 2002: 122). They are able to understand how meaning is made and demonstrate how they have recourse to the linguistic features of authority as they discursively negotiate success with their markers. Students from disadvantaged soicail backgrounds are less able to "negotiate an authoritative self as author and, relying heavily on the words of recognized authorities in the discipline" and thus become a "plagiarizer" (Starfield 2002: 122).

This above review of the literature demonstrates how different identities influence student learning in different contexts. Although most of these studies discuss a single identity at time, one should not assume that single identity is able to explain student learning experience. In fact, different identities interact at the same time, emphasise and inform each other in different contexts (Hall 1990, Bucholtz and Hall 2005). This intersection of different identities is demonstrated in a study about how migrants to Canada learn English as a second language which was reported by Norton and Toohey (2000). The study concluded that interaction of different identities such as gender, social status (migrants), social role (mother, wife), social class (being socially advantaged/disadvantaged in the country of origin) and 
personal history (how they lived in past) influence the way students learn English language. It is suggested that these different identities help explain the student's motivation for learning a language and regulate students' interaction in the classroom (Norton and Toohey 2000). This conclusion echoes the assertion that maintains learning a language is social process where a learner participates in different communities, and that students do not just learn set of vocabulary or grammatical roles, but the meaning of the language is negotiated between the different participants in those learning communities where every participant brings a different set of identities to the interaction (Bakhtin 1988, Lave and Wenger 2001). Mayes (2010) in her recent study using the notions of 'field' and 'capital' theorises how the influence of identities on students' motivation for learning a language. She viewed identity as tool that helps or hinders students to achieve certain gains (capital). According to this analysis a student is seen to develop different capitals inside and outside an educational setting; and these investments seem to influence their learner identity. The investments that a student may, or may not, involved in inside and outside an educational setting (either in the past or now) can influence the way they identify themselves as students. For example, the education of the family, the financial circumstances seem to have great influence on the construction of the current 'student' identity.

Thus, the relationship between identity and language learning is very tight. Many practices of the students in the context of language learning could be explained by this lens. In fact, such a perspective on students' learning experience would provide further insight into how learning is happing inside and outside the language classroom. This dimension in researching students' learning experience has been severely neglected in researching language learning in SA. This article aims to fill in that gap and explore how different identities that learners have in the context of SA influence their EFL learning.

\section{The Context of the Study}

The study described in this paper was conducted in the Saudi Medical University (SMU) in Riyadh. The university is associated with the health affairs of an elite government organization; and the university campuses are physically attended to magnificent hospitals and medical research centres. The mission of the university is to provide educational programmes in healthcare professions. The two main programmes that there university was offering at the time when this data was collected were Medicine and Allied Medical Sciences (AMS); they were taught in English. Students admitted to study in these programmes were Saudi students who do not normally speak English as a first language. In order to meet the linguistic demands of such non-Arabic programmes, the university introduced a three academic semester EFL programme.

In Saudi public universities, Saudi students do not pay tuition fee. This medical university is not an exception to other Saudi universities in term of admission requirements; students with the highest scores in high school are admitted. However, unlike the other Saudi universities, the decision about the disciplines that students are going to study is made at the point of admission and not after the EFL programme. Students with the highest high school results are admitted to study medicine and the rest are admitted to study AMS. During the EFL programme the students are labelled with their prospective discipline of study; the medical students are called pre-med and the AMS students are known as pre-AMS.

Some of the students in this programme studied part or most their pre-university education in grammar (private) school and others in government (public) comprehensive schools. Some of them belong to rich families and others come from disadvantage backgrounds. The educational background of the students' families varies; from those with higher level education to illiterate ones. All these factors seem to play a role in the construction of different identities and subsequently impact on students' learning in the EFL programme.

\section{Methodology}

The data was collected independently as part of my $\mathrm{PhD}$ field work between October 2009 and April 2010. The PhD was sat to investigate the different factors that influence students learning experience (Alhawsawi 2014). Ethnographic methods were used in collecting the data such observation and self-documentation; however, most of the data presented in this paper was obtained through in depth semi-structured interviews with 20 EFL language instructors (native and non-native English speakers). The student sample included 27 students and they were selected randomly from different level of the programme. Most the student interviews were conducted in Arabic and then translated into English which raises different methodological considerations. Culturally and linguistically, English and Arabic are two different languages and thus translating the students' views from Arabic into English was a significant challenge. As a researcher who developed the theoretical framework for this inquiry in English and also as an Arabic speaker, I was able to translate the students' interviews from Arabic into English (Regmi et al. 2010, Temple and Edwards 2008). However, it must be acknowledged that I had to check with other Arabic speakers about my translation of specific concepts that I had in the students' data to validate their translation accuracy. In translating the students' interviews, an attempt was made to maintain neutrality and avoid bias in selecting quotes while making them readable in English. This involved staying close to the literal meaning of what the students expressed in Arabic. However, it was impossible to maintain the literal translation (i.e. word by word) of the quotes, as the literal meaning sometimes did not make sense in English and it was necessary instead to translate to a more general meaning. It was here that effort was made to get a second opinion. Thus the translation style of the students' quotes crossed a fine line between literal and free translation (Honig 1997). 
The interviews with the EFL teacher were conducted in English. Although the data was independently collected, the study was conducted in accordance with the research governance framework of the University of Sussex (http://www.sussex.ac.uk/res/1-6-12.html) and guidelines for research ethics of the School of Education and Social Work (http://www.sussex.ac.uk/esw/research/ethics). This included obtaining the consents of the organization as well as the ones of the participants. For the sake of protecting the anonymity of the participants and the institution, pseudonyms were used conceal the names. Due to the cultural difficulty to accessing female participants, the participants of the study were male students from different semesters of the EFL programme aged between 18-20 years old. They were a mix of pre-med and pre- AMS students. In this study every student was regarded as an individual case and therefore close contact was made with each one in order to gain deep understanding of the learning experience of each individual separately. The data was thematically analysed and compared across cases. This allowed for some commonalities and tension to emerge.

\section{Findings and Discussion}

The analyses of the data showed that identity -among other factors- seem to influence students' learning experience. Different types of identities were observed to have an influence on the students' learning experiences i.e. identity associated with socioeconomic backgrounds; and identity associated with the prospective course the students were intended to study.

\subsection{Identity Associated with Socioeconomic Backgrounds}

In SA, the term 'private' or 'public' education in addition to its reference to the type of education a person can have, it also symbolises associate with advantaged/disadvantaged social background. Generally, in the context of SA being able to offered private education is an indication of advantaged social background. Attending comprehensive public school is often associated with disadvantaged social background. Being schooled in private education often means being able to afford good quality education in the sense of healthy environment, relevant curricula, trained teachers and meaningful outcomes (UNICEF 2000). As reported by AlQifari (No date) and Al-Mesnid (2009) most of the private schools in SA recruit good quality teachers from different nationalities e.g. Arab, Western and Asian. Most of these schools have school days that are two to four hours longer (8 - 10 hours) than public school which is seen to allow the student great exposures to a diversity of extra curricula lessons such as English language, maths, ICT (Al-Mesnid 2009). As these schools are privately run, the required educational resources are often made available for the students (Al-Soheem 2009 and Al-Mesnid 2009). By contrast, despite the great investment in the public school, observers (e.g. Al-Soheem 2009 and Al-Mesnid 2009) of Saudi schooling system suggest that the public schools still suffer mostly from poor quality and careless teachers. In addition, the school days are being disadvantageous in these public schools by being shorter by two or four hours (6 hours) than those in the private schools. Subsequently, there is not enough time for any extra-curricular lessons, but only rigid curricula.

With the deterioration of the quality of education in public schools and the increase in competition among the private schools, Saudi citizens from advantaged backgrounds start to view private education as the best way to educate their children and get them ready for the university life (AlSoheem 2009, Al- Qifari No date and Al-Mesnid 2009). It becomes widely accepted among people in Saudi that being educated in a private school should enable the students to gain a decent level of English language competency, excellent subject knowledge as well as excellent grades; and therefore have better choices when it comes to selecting universities and disciplines. Most publicly educated students, on the other hand, are expected to be less motivated, less serious, possibly excellent in their subject knowledge but mostly weaker in English language competency (Al- Qifari No date and Al-Mesnid 2009).

This discussion about the type school Saudi students attends highlights ways in which social advantages impact on the student identities which consequently influences their learning experiences. Students in SMU, reflecting the values of the wider society, seemed to relate success or failure at university to advantages/disadvantages that they had had by being associated with a particular social background. This privilege was represented in the types of schools the students were able to attend or the academic activities they were able to take part in their pre-university education. Khalid who was not able to enrol in the pre-med track expressed his views about pre-med students by saying:

Most of them [the pre-med] have had private education or have been abroad at some point of their education. They know English; they must have studied it very well and know how to deal with language barriers. Unlike us, when they come here [the Medical University], they feel that the courses are easy and they are appropriate for their level.

Khalid (pre-AMS student)

The above account illustrates many issues. Firstly, it shows students' awareness about the existence of these social differences and the way by which they affect their view about each other. Also, it shows the kind of identity that the students ascribe to each other based on the type school one attends. It seems that they believe coming from advantaged backgrounds help the some students to do better when it comes to English language learning in the university. In addition, it shows how students with disadvantaged background relate their inability to deal with the demands of learning English language to their disadvantaged social background that is represented by the type of school they attended or the activities they were able to participate in. Thus, it is possible to infer that the students were associating being weak and inadequate English language competencies with being publicly educated and being excellent with advanced language competencies with privet education. 
Mayes (2010) and Norton and Toohey (2000) argue that developing such identities that are associated with the type of the backgrounds a person is associated with impacts of the individual learning experiences. Talmy (2010) argues that such an identity influences students' behaviours in the EFL classroom as it may cause them to be alienated. Thus, attending public or private educated is seen as an indicator of particular social class that respectively disadvantage students from disadvantaged background and privileged the ones form advantaged backgrounds.

This identity being socially dis/advantaged did not only influence the students view about each other but it is also being perceived to influence the teachers' views about the students as suggested in the quote below.

I am sure if you conduct a survey, you will be surprised about the huge number of the pre-med students that went to private education that teaches in English or emphasises learning English language. We studied in public schools where nobody cared about English language; the teachers could hardly speak English in the class and hardly explain anything; yet everybody [teachers and the management] here thinks that we don't want to learn.

Hamad (pre-AMS student)

This quote illustrates that the students believe that the negative identity that being constructed based on the type of education attended was not only their held view but also shared by their teachers. This held view by the teachers seems to participate in developing the negative views that these disadvantaged students have about themselves. It makes them feel less legitimate learners in this language programme. This reflects an argument made by Mayes (2010) and Norton and Toohey (2000) when they operationalized Lave and Wenger's (2001) concept of 'community of practices' to explain the sense of legitimacy and belonging in identity. The identity of being privately educated seems to assert the belonging of privately educated students to the community of EFL learners more than the students who attended public education as the former seem to have more familiarity with the practices of the EFL learning or Englishspeaking communities. This is another illustration to the extent to which social backgrounds influence students' learning experience.

This awareness about how an identity that is associated with social background can influence learning is also shared by students who came from privileged social background. They viewed being privately educated as an advantage that their social background allowed them access to; and thus prepared them for the English language demands in the university. In their reflection about the impact that their preuniversity education had on them as learners, Shiyth and Liyth said:

all the pre-med students were the best students in their educational boroughs; ...most of us have had private education through their entire education where we were exposed extensively to English language; and some of us had English language training in private language schools in Saudi or abroad... most of the teachers enjoy teaching us; I don't find the language course very difficult... Shiyth (pre-med student)

I went to a private school. In the secondary school we were the best in our classes; not even the class but the entire year group and everybody was pampering us... in our private schools there were extra curriculum for English language and the teachers were native English.... I guess that helped me a lot in this language programme; I feel I know a lot about the language and I actively participate in the class

Liyth (pre-med student)

The above discussion provides detailed accounts about ways in which social backgrounds influence the student learning experiences in this EFL programme. Advantaged backgrounds allow students access to good quality private education and private English language schools which allowed the students to have positive learning experiences when joining the EFL programme. On the other hand, disadvantaged backgrounds did not enable the students to afford private education or private English language tutoring. Thus, most of them had to put up with the educational challenges that most of the public schools experiences. Subsequently, this is reflected on the way these students are prepared for the university and the kind of learning experiences they had in the EFL programme.

\subsection{Being a Pre-Med or a Pre-AMS Student}

Another type of identity that the date reveals to have an influence on the way the students experience their learning in this EFL programme is associated with the type of discipline they are planning to study i.e. pre-med or pre-AMS. This is in line with Maclean (2010) argument that was alluded to earlier in section 1.3. where suggested that the type of disciplines the students are studying influence their views about themselves and consequently their learning experience In SMU, the students' future courses and future career choices seemed to influence their learning experiences in the EFL programme. In the context of this study, when the students are accepted to study in SMU, they are immediately streamed into pre-med or pre-AMS, based on their grades in high schools. High achiever students are admitted to study medicine after they finish successfully the EFL programme and low achiever students are admitted to study Allied Medical Science courses after they successfully pass the EFL programme. Although prior to the start of the language programme these students are classified according to their results from high schools into pre-med and pre-AMS, they were expected to study similar EFL programme and go through symmetrical assessment process. This early classification of the students seems to influence the students' views about themselves as well as the others view them in the EFL programme as demonstrated in the data. The data shows that student in the pre-med groups believed that being in a groups that are marked as high achievers influence their learning experiences in a positive way. It boosted their confidence when it came to classroom activities and practices as suggested in the quotes below. 
As a student who is going to study medicine, I needed to learn to personalize the knowledge, own it and keep it with me all the time; and not just to learn for exams.

Idrees (pre-med student)

We are still in the pre-medicine phase where we need to demonstrate that we are capable of studying medicine

Ibraheem (pre-med student)

Teachers in the EFL programme seemed to participate in developing this identity of being high achievers that is associated with pre-med groups. This is illustrated in the quote below when Idrees comparing his pre-med group with pre-AMS.

They [pre-AMS students] are the worse in term of English language abilities; and some of them don't know English language at all. We hear from the teachers that most the EFL Arab teachers are teaching these groups. They help them to learn the language as it would be extremely difficult for them to communicate with the English native speaker teachers. For us -pre-medicine students-all of our teachers are English native speaker."

Idrees (pre-med Student)

The quote above shows how some EFL teachers portrayed the students in these two different groups. Positive and negative pictures were portrayed about pre-med and preAMS respectively. In addition, the quote shows how such an image could send positive messages to students in pre-med groups and negative message about students in pre-AMS groups. Furthermore, the quote shows ways in which premed students legitimized themselves as EFL learners who had strong association with centre of the EFL 'community of practices' that is presented in being taught with native English language teachers. These messages were not only observed from the student interviews but they are also obvious form interviews with EFL teachers.

My impression is that pre-Meds are more serious, generally speaking than pre- AMS. They're more careers focused than the AMS students who are training to be lab techs and also training to be technicians. What I don't know is where the pre-meds get that from. [...] But there seems to be that dichotomy there.

Breandan (EFL teacher)

Most of the pre-AMS students don't know or understand what Allied Medical Sciences is and don't know what career they are going to join. Most of them join the programme without having clear pictures about the discipline. It is probably much clear for the pre-medicine students because the medicine itself as discipline is much clearer. These students know that they are going to study medicine and they are going to be doctors and they can figure out what they need to do prepare themselves to becoming medicine students.

Alroy (EFL teacher)

These quotes above show the held views that some EFL teachers had about students in the pre-med groups. They viewed pre-med students as very serious, career-focussed, interested, smart students who were always well-informed about their learning. What is interesting here is that some teachers related such positive characteristics that were associated with pre-med students to the discipline itself and that becoming a physician has clear process that students should follow. In addition, this realization and the positive views that most EFL teachers had about the pre-med students made them feel able to achieve higher goals as suggested in the quote below:

The pre-med guys did show interests in understanding the objective of their learning and what they need to do; the pre-AMS honestly didn't. Generally speaking the pre-med many of them- think they're smarter than they actually are. And because of that it's important to gain their trust [...]. In pre-med it's important to get them understand the goal right away so that they can focus on the goal.

Coilin (EFL teacher)

This quote shows how identity play role in help students to have better self-esteem which can influence their achievement. This teacher knew that the some students in pre- med were not as smart as they may come across but it is that the group to which they were assigned with had a positive influence on the way he viewed these students. Students in the pre-med groups were aware of such positive views held by the EFL teachers. This made them tried all the time to rise up to the challenge and push their learning boundaries beyond their comfort zone so they were able to maintain the image of being high achievers.

Once I knew that I was going to study medicine, my entire attitude to study has changed. I always want to learn about almost everything; it has nothing to do with maintaining my status as one of the best student in the class but it is about maintaining the status of being prospective medicine student; and that requires hard work. Malik (pre-med Student)

On the other hand, students in pre-AMS groups felt different to their counterparts in pre-med groups from the first day in the EFL programme. They were treated as less intelligent and different in a negative way.

we have always been compared with students in premedicine groups in negative ways. The teachers used to ask us why we weren't like the pre-medicine students. They used to say that whenever they used to ask question in the pre-medicine groups may students used to jump to answer it; and why we were like that; only few of us were always participating and the others weren't. Teachers always used to emphasise these differences and-to be honest- that was de-motivating.

Yusuf (pre-AMS Student)

This realization of being different that was stemmed from being associated with pre-AMS seemed to influence the students learning in a negative way. It appeared to have caused them to doubt their motivations and lower their selfesteem; and thus impact negatively on their participations in the classroom. Khalid, a pre-AMS student, commented on the negative impact such teachers' held views had on him by saying:

...when someone treats you that like a donkey [not smart] everyday surely that would affect your ability at some 


\section{point}

Khalid (pre-AMS Student)

These teachers' negative views were not only reported by the students, but were expressed by some EFL teachers in the programme as it can be observed from the quotes of the EFL teachers, Alroy and Breandan, above. In those quotes preAMS students were depicted as inferior to pre-med students, less serious, less career-focussed, less interested, and 'intellectually inferior' who did not have a say about their learning. This depiction can be seen clearly in the quote below when a teacher was talking about students in pre-AMS groups:

In pre-AMS I've learnt that it's better not to give any information at all. Let them walk like blind sheep through dark valley, as long as they follow you blindly it's ok". Coilin (EFL teacher)

The students in the pre-AMS groups generally seemed to be annoyed with such negative comparisons and the negative views that being ascribed to their groups by both teachers and students. This contributes to the awkwardness of the situation as it deepened the feeling of being low achievers that most pre-AMS students were battling with as expressed in this quote.

It is because of the negative massages that we have been getting form everybody that we aren't as good as the premedicine; I can feel that students in the pre-AMS aren't so motivated and everybody thinks that we should be treated differently because most of us are slow learners and that affects the way the group is today"

Hussam (pre-AMS Student)

Having said that one must acknowledge that there were some students in the pre-AMS groups who contested and challenged this ascribed negative identity. Students in preAMS like Yusuf worked hard to prove themselves as excellent high achiever students as shown in the quote below.

Ever since the programme stared, I have been working really hard to improve my language competency, despite the negative images that is associated with our groups. Do you know that I am among the top-five high achiever in this EFL programme...; I help my classmates and encourage them to improve as group...

Yusuf (pre-AMS Student)

Furthermore, although most of the pre-AMS students were located to these groups because they could not make to medicine, some students were in pre-AMS groups because it was their first choice and the wanted to study this disciplines as noted in the quote below.

I have always wanted to study laboratory... originally, I was admitted to study medicine and I didn't accept it and I asked to be transferred to applied medical sciences (preAMS)... I just love working in laboratory...

Salim (pre-AMS Student)

To sum up, the identity that is associated with the subject or discipline of study affects students view about themselves and affect the others views' about them. This consequently makes the students behave in certain ways; and that has an influence on their learning experience. In this case, it induced pre-med students to improve their learning abilities and progress academically while inducing students in pre-AMS to be apprehensive, uncertain and conscious about their learning and academic progress. The terms pre-med or preAMS are associated with many social symbols in the context the EFL programme in SMU. Despite that fact that they are still students in their preparation phase to become medicine or AMS students, it could be argued that the 'pre-med' identity is associated with better achievements and the 'preAMS' has much more negative connotations. Generally, the positive/negative experiences that students had in this EFL programme could be correlated with these explicit or implicit identities that they had about themselves as well as the ones that educational setting hold about them.

\section{Conclusion}

The paper shows how different identity influence students' learning experience in the EFL programme in SMU. These identities associated with socioeconomic background and disciplines of the study. The paper suggests that students who are identified as socially advantaged have positive learning experiences in the language programme because of the privileged that they acquired from their social background which allowed them to deal confidently with demand of studying EFL in the university. Student who are associated with disadvantaged background express negative experiences in the programme due to the lack of advantaged educational opportunities that their social background deprived them from. The discipline the students are going to study in the university after finishing successfully the language programme created particular identity for the students. Being part of the group that was going to study medicine provided the student with positive attitude about learning English as well as paves the way for their success. Student associated with the group who were not going to study medicine are ascribe negative characteristic that shown to have negative impact of these students learning experience. It is important to note that in the case some students there more than one type of reported identity interfere in influence student learning. This is not to say that this dose happen in the case of the rest of the students but it did not come clear in the data. These different identities discussed in this paper individually or collectively specifically influence student learning in term of motivation, learning aptitude, participation in class room activities as well as availability of study time.

This paper highlight the importance of understanding students' identities in EFL programme in SA as this helps in understanding the relationship between the learners and the real world and emphasises the influence of identities in the process of knowledge production and language learning. Also, it shows how educational academic settings incentive or disadvantage students with certain identity. Teachers un/consciously participate in advantaging or disadvantaging the students. This poses questions about the extent to which education is used a tool for empowering students. Thus, this paper suggests a special attention to be paid in these EFL 
programmes to issues related to identity and encourages practitioners to be reflective. This could help reduces the negative impact of identity and foster positive influence on student' learning experience.

\section{References}

[1] Al-Abed Al Haq, F. \& Smadi, O. (1996) Spread of English and Westernization in Saudi Arabia. World Englishes. Vol. 15(3) pp. 307-317.

[2] Alhawsawi, S. (2014) Investigating Student Experiences of Learning English as a Foreign Language in a Preparatory Programme in a Saudi university. PhD. Thesis. The University of Sussex. UK, Brighton.

[3] Al-Mesnid, A. (2009) The Increasing of the Instalments of Private Education. Available from: http://knol.google.com [accessed on 13th Aug. 2010].

[4] Al-Qifari, A. (ND) The private education in Saudi: does it increase the gap among the society? Available from: http://www.bab.com/articles/full article.cfm?id=2163 [accessed on 28th Aug 2011].

[5] Al-Shehri, A. (2009) Motivation and vision: The relation between the ideal L2 self, imagination and visual style. In Ushioda, E (Ed.). Motivation, language identity and the L2 self. Available from: http://books.google.co.uk/books?hl=en\&lr=\&id=59fl2aQLSB sC\&oi $=$ fnd\&pg $=$ PR7\&dq=Motivation,, language + identity + an $\mathrm{d}+$ the $+\mathrm{L} 2+$ self $\&$ ots $=$ pWo-r6A5va\&sig $=$ WC-H-

iak5ZvvbKptgC5dKErotiQ $\# \mathrm{v}=$ onepage $\& \mathrm{q} \& \mathrm{f}=$ false. [accessed on13th September 2010].

[6] Al-Soheem, K. (2009) The Private Education in The Kingdom: Innovation or Repetition. Al-Marefh Journal (Arabic). Vol. 56. Available http://www.almarefh.org/news.php?action=show\&id=3687 [accessed on 13th Aug. 2010].

[7] Ashwin, P. (2009) Analysing teaching-learning interactions in higher education: Accounting for structure and agency. Continuum:??

[8] Bakhtin, M. (1988). The prehistory of novelistic discourse. In Lodge, D. (Ed.). Modern criticism and theory: A reader. New York: Longman.

[9] Barnawi, O. (2009) The Construction of Identity in L2 Academic Classroom Community: A Small Scale Study of Two Saudi MA in TESOL Students at North American University. Journal of Language and Linguistic Studies. Vol. 5 (2)

[10] Becher, T., Parry, S., (2005) The endurance of disciplines, in: In Ivar Bleiklie and Mary Henkel [edt]. Governing knowledge: A study of community and change in higher education. Springer, New York.

[11] Becher, T., Trowler, P.R., (2001) Academic tribes and territories. The Society for Research into Higher Education \& Open University Press, Buckingham.

[12] Biggs, J., (1993) What do inventories of students' learning processes really measure? A theoretical review and clarification. British Journal of Educational Psychology. Vol. 63, pp. 3-19.

[13] Biggs, J., (2001) The reflective institution: Assuring and enhancing the quality of teaching and learning. Higher Education. Vol. 41, pp. 221-238.

[14] Bucholtz, M. \& Hall, K. (2005) Identity and interaction: a sociocultural linguistic approach. Discourse Studies. Vol. 7 pp. 585-614.

[15] Entwistle, N.J., Ramsden, P., (1982) Understanding student learning. ERIC, London.

[16] Hall, S. (1990) Cultural Identity and Diaspora. In Rutherford J (Ed.). Identity: Community, Culture, Difference. London: Lawrence \& Wishart.

[17] Honig, H. G., (1997) Positions, power and practice: Functionalist approaches and translation quality assessment. Current Issues in Language \& Society. Vol. 4, pp. 6-34.

[18] Lave, J., Wenger, E., 2001. Legitimate peripheral participation in communities of practice. Supporting Lifelong Learning: Perspective on Learning 1, 111-126.

[19] Lea, M.R., Stierer, B., (2000) Student writing in higher education: new contexts. Open University Press, London.

[20] Maclean, R. (2010) First-year law students' construction of professional identity through writing. Discourse Studies. Vol. 12(2) pp. 177-194 http://dis.sagepub.com/content/12/2/177

[21] Mayes, P (2010) The discursive construction of identity and power in the critical classroom: Implications for applied critical theories. Discourse \& Society. Vol. 21(2), pp.189-210.

[22] McKinney, C. \& Norton, B. (2008) Identity in Language and Literacy Education. In Spolsky, B. \& Hult, F.: The Handbook of Educational Linguistics. Available from: http://onlinelibrary.wiley.com/doi/10.1002/9780470694138.ch 14/summary [accessed 26th Aug 2010].

[23] McMullen, M. (2009) Using language learning strategies to improve the writing skills of Saudi EFL students: Will it really work? Available from: http://www.sciencedirect.com/science?_ob=MiamiImageURL $\&$ cid $=271757 \&$ user $=128558 \&$ pii $=\bar{S} 0346251$ X09000578\& check $=$ y\&_origin $=\&$ coverDate $=30-$ Sep2009\&view $=$ c\&wchp $=$ dGLbVlkzSkzS\&md5=b138875244135b896a5c05b41c2b7fbd/1-s2.0S0346251X09000578-main.pdf. [accessed on 30th August 2010].

[24] Norton, B. and Toohey, K. (2000) Critical pedagogies and language learning in Race, culture, and identities in second language education exploring critically engaged practice. Cambridge: CUP

[25] Peirce, B. (1995) Social Identity, Investment, and Language Learning. TESOL Quarterly Vol. 29(1) pp. 9-31.

[26] Regmi, K., Naidoo, J., Pilkington, P. (2010) Understanding the processes of translation and transliteration in qualitative research. International Journal of Qualitative Methods. Vol. 9, pp. 16-26.

[27] Solomon, Y., 2007. Not belonging? What makes a functional learner identity in undergraduate mathematics? Studies in Higher Education. Vol. 32, pp. 79-96.

[28] Starfield, S. (2002): "I'm a Second-Language English Speaker": Negotiating Writer Identity and Authority in Sociology One. Journal of Language, Identity \& Education. Vol. 1(2) pp. 121-140. Available from: http://dx.doi.org/10.1207/S15327701JLIE0102 02 [accessed on 15 Feb 2012]. 
[29] Talmy, S. (2010): Becoming "Local" in ESL: Racism as Resource in a Hawai'i Public High School. Journal of Language, Identity \& Education. Vol. 9(1) pp. 36-57. Available from: http://dx.doi.org/10.1080/15348450903476840 [accessed on $15 \mathrm{Feb} 2012]$

[30] Temple, B., Edwards, R., (2008) Interpreters/translators and cross-language research: Reflexivity and border crossings. International Journal of Qualitative Methods. Vol. 1, pp. 1-12.

[31] Trowler, P. \& Cooper, A. (2002) Teaching and Learning Regimes: Implicit theories and recurrent practices in the enhancement of teaching and learning through educational development programmes. Higher Education Research \& Development. Vol. 21(3) pp. 221-240.
[32] Trowler, P., 2009. Beyond Epistemological Essentialism: Academic tribes in the twenty first century, in: Kreber, C. [edt.]. The university and its disciplines: Teaching and learning within and beyond disciplinary boundaries. Routledge, London.

[33] UNICEF (2000) Defining Quality in Education. Available from: http://www.unicef.org/education/files/QualityEducation.PDF. Accessed on 27th April 2015.

[34] Vann, V. \& Abraham, R. (1990) Strategies of Unsuccessful Language Learners. TESOL Quarterly. Vol. 24(2) pp. 177-198.

[35] Weedon, C. (1997) Feminist Practice and Poststructuralist Theory (2nd edn.) Oxford: Blackwell. 